Goldschmidt 2021 Abstract

https://doi.org/10.7185/gold2021.5419

\section{SHALLOW MAGMA MIXING ABOVE THE OCCIDENTAL BOUNDARY OF ALTIPLANO PUNA MAGMA BODY: CONSTRAINING THE GEOTHERMAL HEAT SOURCES THROUGH THE CASE OF AZUFRE VOLCANO}

\author{
DARÍO HÜBNER ${ }^{1,2}$, MIGUEL ANGEL PARADA ${ }^{1,2}$, \\ EDUARDO MORGADO ${ }^{2,3}$ AND FRANCISCA MALLEA- \\ LILLO $^{1,2}$
}

${ }^{1}$ University of Chile

${ }^{2}$ Andean Geothermal Center of Excellence, CEGA

${ }^{3}$ University of Leeds

Presenting Author: dariosalvadorhubner@gmail.com

In the context of researching the heat sources that feed the Cerro Pabellón geothermal system (Northern Chile), we study the origin of the youngest andesitic (61-63 $\mathrm{SiO}_{2} \mathrm{wt} \%$ ) lava flow from the Azufre volcano $\left(21^{\circ} 47^{\prime} 7^{\prime \prime} \mathrm{S} ; 6^{\circ} 14^{\prime} 23 \mathrm{~W}\right)$. This stratovolcano is emplaced over a $70 \mathrm{~km}$ long NW-SE alignment above the occidental boundary of Altiplano Puna Magma Body (which is the largest active magma body on Earth) and located 10 $\mathrm{km}$ NW from the first geothermal power plant of South America. The significance of this volcano relies on the younger volcanic units developed around it ( $<150 \mathrm{ky}$ ), which correspond to dacitic domes (Chanca, Chac Inca and Cerro Pabellón; see figure 1) and our studied holocrystalline lava flow. This flow comprises aphanitic andesite enclaves (58-60 $\mathrm{SiO}_{2} \mathrm{wt} \%$ ) and phenocrysts of plagioclase, amphibole, biotite and orthopyroxene (15, 4, 4, 2 in vol\%, respectively) together with scarce phenocrysts of clinopyroxene, quartz and olivine ( $\sim$ in vol\% each one). The groundmass of lava and enclaves is made up of the same mineral chemistry, displaying amphibole microphenocryts and microlites of plagioclase, pyroxenes and $\mathrm{Fe}-\mathrm{Ti}$ oxides.

We use different geobarometric and geothermometric techniques in phenocrysts and microlites along with crystallization simulations performed in MELTS freeware to study the magmatic evolution and identify a zoned crystal-mush magma reservoir emplaced at shallow crustal levels $(\sim 6,4 \mathrm{~km}$ of depth). In this way, based on textural features, mineral chemistry and thermometry results, an open system with two zones (Zone A and B) was identified for the magmatic system that fed the youngest lava flow of the Azufre volcano. Zone A (at high temperatures in the range of $916-1097^{\circ} \mathrm{C}$ ) would represent a deep recharge zone where primitive melt (of composition similar to enclaves) intruded the bottom of the Zone B, which corresponds to a more evolved siliceous crystal-mush reservoir (at lower temperatures between $712-799^{\circ} \mathrm{C}$ ). Thereby, during this incomplete magma mixing was made the magma chamber that trigged the last eruption stage of the Azufre volcano.

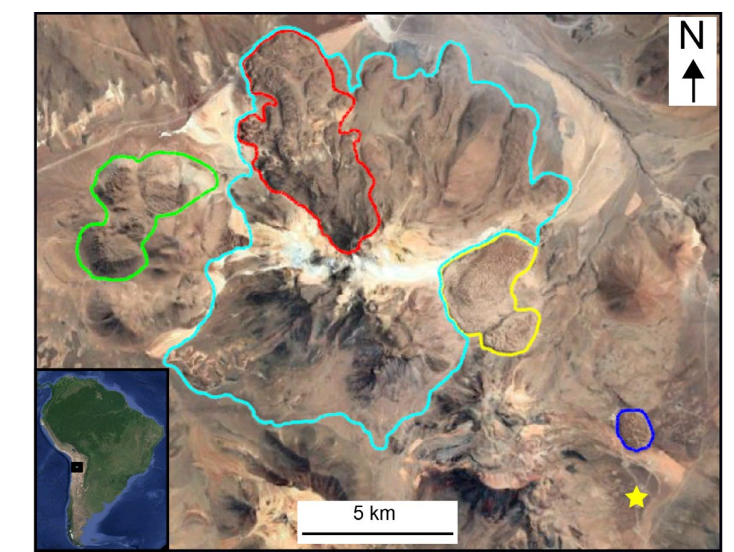

Figure 1: Satellite image highlighting the locations of the geothermal power plant (yellow star),the Azufre volcano (cyan line), the holocrystalline lava flow studied (red line) and the others younger volcanic units: Cerro Pabellón dome (blue line), Chac Inca dome (yellow line) and Chanca dome (green line). 